\title{
Penyelesaian Masalah Optimisasi Multiobjektif Nonlinear Menggunakan Pendekatan Pareto Front dalam Metode Pembobotan
}

\author{
SYARIFAh INAYATI ${ }^{1}$, RAhMAWATI $^{2}$ \\ ${ }^{1}$ Program Studi Statistika, Fakultas MIPA, Universitas Negeri Yogyakarta, \\ Jl. Colombo Nomor 1 Yogyakarta 55281 \\ ${ }^{2}$ Prodi Matematika, Fakultas Sains dan Teknologi, UIN Sultan Syarif Kasim Riau, \\ Jl. HR Soebrantas No. 155 KM. 15, Panam-Pekanbaru 28293 \\ Email: ${ }^{1}$ syarifah.inayati@uny.ac.id, ${ }^{2}$ rahmawati@uin-suska.ac.id
}

\begin{abstract}
Abstrak
Teori optimisasi merupakan salah satu disiplin ilmu matematika yang banyak diterapkan dalam dunia nyata. Hampir semua masalah optimisasi di dunia nyata memiliki banyak fungsi objektif (multi-objective) yang harus dipenuhi secara simultan dan seringkali fungsi-fungsi tersebut saling bertentangan. Permasalahan optimisasi yang ada dapat berbentuk linear dan nonlinear. Dalam paper ini dibahas secara teoritis mengenai permasalahaan multiobjektif nonlinear dengan menerapkan pendekatan Pareto Front untuk menyelesaikan optimisasi pada permasalahan multiobjektif nonlinear. Metode pembobotan (weighted sum method) digunakan untuk memformulasikan fungsi multiobjektif menjadi fungsi tujuan tunggal. Himpunan Pareto optimal (Pareto-optimal front), yang merupakan kumpulan solusi yang dihasilkan, berhasil ditentukan melalui pendekatan ini. Pembahasan dilengkapi dengan suatu ilustrasi contoh numerik.

Kata kunci: Metode pembobotan, optimisasi multiobjektif nonlinear, Pareto front.
\end{abstract}

\begin{abstract}
Optimization theory is a mathematical discipline that is widely applied in the real world. Almost all optimization problems in the real world have multiple objective (multi-objective) functions that must be fulfilled simultaneously and these functions conflict with each other. The existing optimization problems can be linear and nonlinear. The paper is discussed theoretically regarding nonlinear multi-objective problems by applying the Pareto Front approach to solve the optimization of nonlinear multi-objective problems. The weighting method (weighted sum method) is used to formulate a multi-objective function into a single objective function. The Pareto-optimal front, which is the resulting set of solutions, is determined by this approach. The discussion is completed with an illustrative numerical example.

Keywords: Weighted sum method, multi-objective nonlinear optimization, and Pareto front.
\end{abstract}

2010 Mathematics Subject Classification: $90 \mathrm{C} 29$

Submitted: 2020-08-30, Revision: 2020-09-30, Accepted: 2020-09-30. 


\section{Pendahuluan}

Optimisasi adalah salah satu disiplin ilmu yang dalam penerapannya difokuskan untuk mendapatkan nilai minimum atau maksimum dari suatu fungsi yang memenuhi semua fungsi kendala yang diberikan. Permasalahan optimisasi yang ada dapat berbentuk linear dan nonlinear. Dalam permasalahan pengambilan keputusan yang penting dalam dunia nyata seringkali memerlukan penyelesaian yang harus memenuhi kendala yang ada dan mengarah pada permasalahan kompleks $[1,9,10,4]$.

Banyak permasalahan penting yang selalu melibatkan fungsi tujuan lebih dari satu atau multiobjektif (multi-objective) yang harus dipenuhi secara simultan dan seringkali fungsi-fungsi tersebut saling bertentangan. Masalah optimisasi multiobjektif dapat ditemukan dalam banyak situasi, misalnya, dalam desain produk di mana beberapa kriteria harus dipenuhi secara bersamaan [8], atau portofolio keuangan pengelolaan dimana perlu untuk menemukan trade-off antara pengembalian portofolio dan risiko volatilitasnya $[6,3]$.

Model permasalahan yang dihasilkan tidak hanya berbentuk linear, tetapi terdapat model yang berbentuk nonlinear. Oleh karena itu, sampai saat ini banyak penelitian mengenai penyelesaian masalah optimisasi nonlinear. Penerapan masalah optimisasi multiobjektif pada portofolio keuangan misalnya pada investasi saham. Pada masalah optimisasi ini, peluang keuntungan harus dimaksimumkan dan secara bersamaan risiko harus diminimumkan. Untuk mengoptimumkan (memaksimumkan/ meminimumkan) satu fungsi objektif maka harus mengorbankan fungsi objektif yang lain. Mendapatkan satu solusi dan mengukur seberapa baik solusi ini dibandingkan solusi-solusi yang lain merupakan tujuan utama penyelesaian masalah ini.

Banyak masalah optimisasi multiobjektif tidak akan didapatkan solusi optimum tunggal tapi berupa kumpulan solusi alternatif, karena tidak ada sebuah solusi yang lebih baik terhadap solusi lain jika semua fungsi objektif dipertimbangkan. Kumpulan solusi tersebut disebut himpunan pareto optimal [5, 7]. Himpunan Pareto optimal tersebut berkorespondensi dengan Pareto front optimal. Jika Pareto front optimal tersebut konveks, maka solusi masalah ini dapat diselesaikan dengan metode pembobotan (weighted sum method) [2].

Dalam penelitian ini memaparkan masalah multiobjektif nonlinear dengan menerapkan metode Pareto Front untuk menyelesaikan optimisasi pada permasalahan multiobjektif nonlinear. Metode pembobotan digunakan untuk memformulasikan fungsi multiobjektif menjadi fungsi tujuan tunggal. Apabila telah diperoleh fungsi tujuan tunggal, maka dapat diperoleh solusi optimal dengan metode penyelesaian permasalahan program linear yang ada seperti metode grafik atau metode simpleks. Ilustrasi contoh numerik diberikan untuk memperjelas konsep dan metode penyelesaian masalah ini.

\section{LANDASAN TEORI}

Masalah optimisasi multiobjektif merupakan masalah optimisasi yang meminimumkan atau memaksimumkan fungsi tujuan lebih dari satu fungsi tujuan dengan himpunan kendala berbentuk pertidaksamaan.

Definisi 2.1. [11] Masalah Optimisasi Multiobjektif memuat himpunan n parameter (variabel keputusan), himpunan $k$ fungsi objektif dan himpunan $m$ kendala. Fungsi objektif dan kendala adalah fungsi dari parameter tersebut. Tujuan optimisasi adalah:

$$
\begin{aligned}
& \text { Memaksimumkan: } y=f(x)=\left(f_{1}(x), f_{2}(x), f_{3}(x), \ldots, f_{k}(x)\right) \\
& \text { dengan kendala:e }(x)=\left(e_{1}(x), e_{2}(x), e_{3}(x), \ldots, e_{m}(x)\right) \leq 0 \\
& \text { dengan: } x=\left(x_{1}, x_{2}, x_{3}, \ldots, x_{n}\right) \in X \\
& y=\left(y_{1}, y_{2}, y_{3}, \ldots, y_{n}\right) \in Y
\end{aligned}
$$

dan $x$ adalah vektor keputusan dan $y$ adalah vektor objektif, $X$ adalah ruang keputusan dan $Y$ disebut ruang objektif. Kendala $e(x) \leq 0$ menentukan himpunan penyelesaian feasible (layak). 
Definisi 2.2. [11] Himpunan feasible $X_{f}$ didefinisikan sebagai himpunan vektor keputusan $x$ yang memenuhi kendala $e(x)$ :

$$
X_{f}=\{x \in X \mid e(x) \leq 0\}
$$

Image $X_{f}$ adalah daerah feasible dalam ruang objektif yang dinyatakan sebagai:

$$
Y_{f}=f\left(X_{f}\right)=\cup_{x \in X_{f}}\{f(x)\}
$$

Tanpa mengurangi keumuman, dalam penelitian ini diasumsikan untuk masalah memaksimumkan. Untuk masalah meminimumkan atau masalah campuran antara meminimumkan dan memaksimumkan dapat didefinisikan secara analog.

Sebagai contoh, dimisalkan bahwa dua objektif yakni kinerja dan biaya menjadi dimaksimalkan dalam ukuran kendala. Kemudian design optimal bisa saja diperoleh dengan memaksimumkan kinerja dan meminimumkan biaya asalkan tidak melampaui batas. Jika penyelesaian masing-masing ada, sebenarnya hanya menyelesaikan masalah optimisasi biasa (satu fungsi objektif). Solusi optimal untuk fungsi objektif tersebut juga akan optimal untuk fungsi objektif yang lain.

Permasalahan optimisasi multiobjektif menjadi sangat rumit disebabkan oleh situasi yang biasa ketika satu keoptimalan berkorespondensi dengan fungsi objektif yang cukup berbeda. Dengan demikian, objektivitas tersebut berlawanan dan tidak dapat dioptimalkan secara simultan. Pada contoh yang diberikan, masalah kinerja dan biaya adalah hal yang berbanding lurus, saat diinginkan kinerja yang baik (dalam hal ini maksimal) dibutuhkan biaya yang cukup besar sedangkan dengan biaya yang rendah biasanya menghasilkan kinerja yang lebih buruk. Namun, untuk memenuhi keinginan pasar, yakni ingin kinerja yang baik dengan biaya yang rendah, diambil penyelesaian tengah (intermediate solutions) yang tepat untuk masalah di pasaran. Masalah ini dapat diselesaikan dengan masalah optimisasi multiobjektif.

Pada masalah optimisasi dengan fungsi tujuan tunggal (optimisasi single objektif), himpunan feasible (layak) secara utuh terurut berdasarkan fungsi objektif, untuk setiap dua solusi $a, b \in X_{f}$ maka $f(a) \geq f(b)$ atau $f(b) \geq f(a)$. Tujuannya adalah mencari penyelesaian yang memberikan nilai optimal dari f. Namun, ketika beberapa objektif dilibatkan maka situasi berubah menjadi secara umum tidak terurut seluruhnya namun hanya terurut sebagian. Pada Gambar 1, penyelesaian direpresentasikan oleh titik B yang lebih baik dari solusi titik C, berarti didapat kinerja yang lebih baik dengan biaya yang rendah. Di lain pihak untuk mempersingkat situasi ini, secara sistematis, relasi $=, \geq,>$ diperluas pada vektor objektif yang dianalogikan seperti pada kasus optimisasi single objektif.

Definisi 2.3. Untuk setiap dua vektor objektif $u$ dan $v$ :

$u=v$ jika hanya jika, $\forall i \in\{1,2,3, \ldots, k\} \sim u_{i}=v_{i}$

$u \geq v$ jika hanya jika, $\forall i \in\{1,2,3, \ldots, k\} \sim u_{i} \geq v_{i}$

$u>v$ jika hanya jika, $\forall i \in\{1,2,3, \ldots, k\} \sim u_{i}>v_{i}$

Untuk relasi $\leq$ dan $\geq$ didefinisikan secara analog.

Menggunakan Definisi 2.3, $B>C, C>D$ maka $B>D$ : dengan membandingkan B dan E, maka kita tidak dapat mengatakan mana yang lebih baik, karena $B \ngtr E$ dan $E \ngtr B$. Walaupun solusi direpresentasikan oleh $E$ adalah lebih murah, tapi kondisi ini akan menghasilkan kinerja yang lebih buruk daripada $B$.

\section{Hasil dan Pembahasan}

3.1. Pareto-optimal Front. Jika diberikan dua vektor keputusan $a$ dan $b$ dengan masalah optimisasi multiobjektif dapat dibuat tiga kemungkinan relasi $\geq$ yaitu $f(a) \geq f(b), f(b) \geq$ $f(a)$ atau . Lebih lanjut, simbol-simbol digunakan hanya untuk klasifikasi situasi yang berbeda.

Definisi 3.1. (Dominasi Pareto) Untuk setiap dua vektor keputusan $a, b$ :

$a \succ b$ (a mendominasi b) jika hanya jika $f(a)>f(b)$

$a \succcurlyeq b$ (a mendominasi lemah $b$ ) jika hanya jika $f(a) \geq f(b)$ 


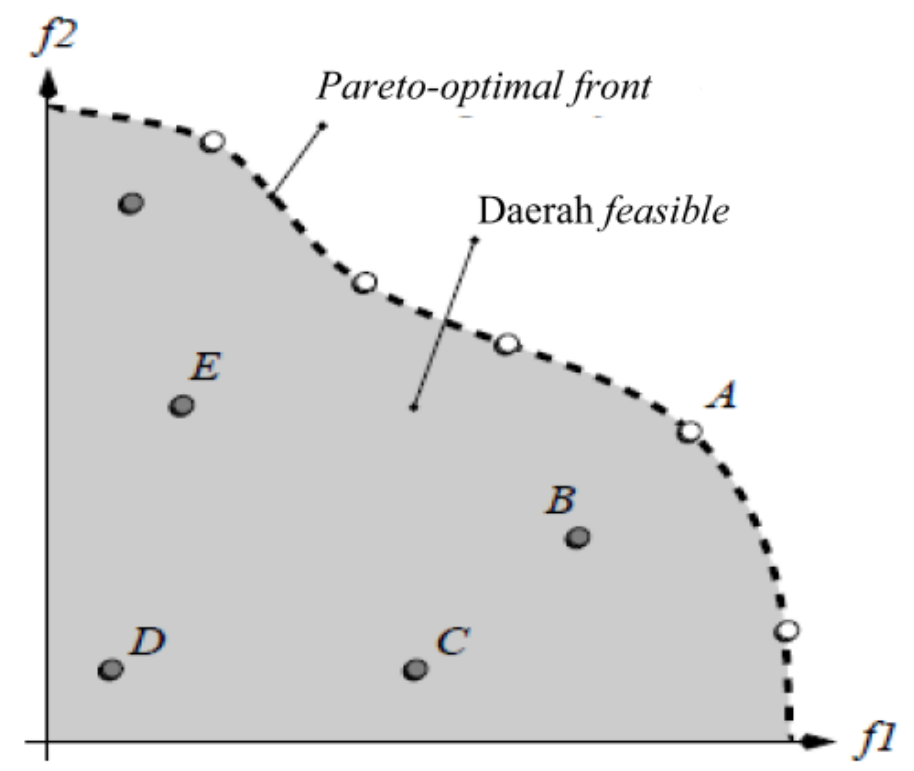

Gambar 1. Daerah feasible dan Pareto-optimal front

$a \sim b$ (a tidak berbeda dengan b) jika hanya jika $f(a) \ngtr f(b) \wedge f(b) \nsupseteq f(a)$

Untuk meminimumkan masalah $(\succ, \succcurlyeq, \sim)$ didefinisakan secara sama.

Pada Gambar 2, segiempat berwarna abu-abu terang memuat vektor objektif pada ruang objektif yang didominasi oleh vektor keputusan yang direpresentasikan oleh B. Segiempat abuabu gelap memuat vektor objektif yang mendominasi vektor keputusan yang direpresentasikan dengan B. Semua solusi yang menghasilkan vektor objektif adalah bukan pada kedua segiempat yang direpresentasikan oleh B.

Dari konsep Dominasi Pareto di atas, kriteria optimalitas untuk optimisasi multiobjektif dapat didefinisikan sebagai berikut:

Definisi 3.2. Vektor keputusan $x \in X_{f}$ dikatakan tidak terdominasi oleh himpunan $A \subseteq X_{f}$ jika dan hanya jika tidak ada a sehingga $a \succ x$. Dalam hal ini A jelas maksudnya, lebih lanjut $x$ dikatakan pareto optimal jika dan hanya jika $x$ tidak terdominasi $X_{f}$.

Keseluruhan dari penyelesaian optimal Pareto disebut himpunan optimal Pareto, yang berkorespodensi dengan vektor objektif Pareto-optimal front atau luasan. Himpunan optimal Pareto ini seringkali disebut juga Pareto set, Pareto front, Pareto frontier, atau Pareto boundary.

Definisi 3.3. (Himpunan Tak Terdominasi dan Bidang Tak Terdominasi) Diberikan $A \subseteq X_{f}$. Fungsi $p(A)$ merupakan himpunan vektor keputusan tak terdominasi di A, yakni. $p(A)=\{a \in A \mid$ a tidak terdominasi oleh $A\}$. Himpunanp $(A)$ adalah himpunan tak terdominasi oleh $A$, himpunan korespodensi dari vektor objektif $f(p(A))$ adalah bidang tak terdominasi oleh A. Lebih lanjut, himpunan $X_{p}=p\left(X_{f}\right)$ disebut himpunan Pareto optimal dan himpunan $Y_{p}=f\left(p\left(X_{f}\right)\right)$ dinyatakan sebagai Pareto-optimal front.

Himpunan optimal pareto terdiri dari penyelesaian optimum global. Dilain pihak, pada masalah single objektif terdapat pula optimal lokal yang merupakan himpunan tak terdominasi dalam persekitaran tertentu. Hal ini berkorespodensi dengan konsep himpunan global dan lokal Pareto optimal berikut:

Definisi 3.4. Diberikan himpunan vektor keputusan $A \subseteq X_{f}$ 


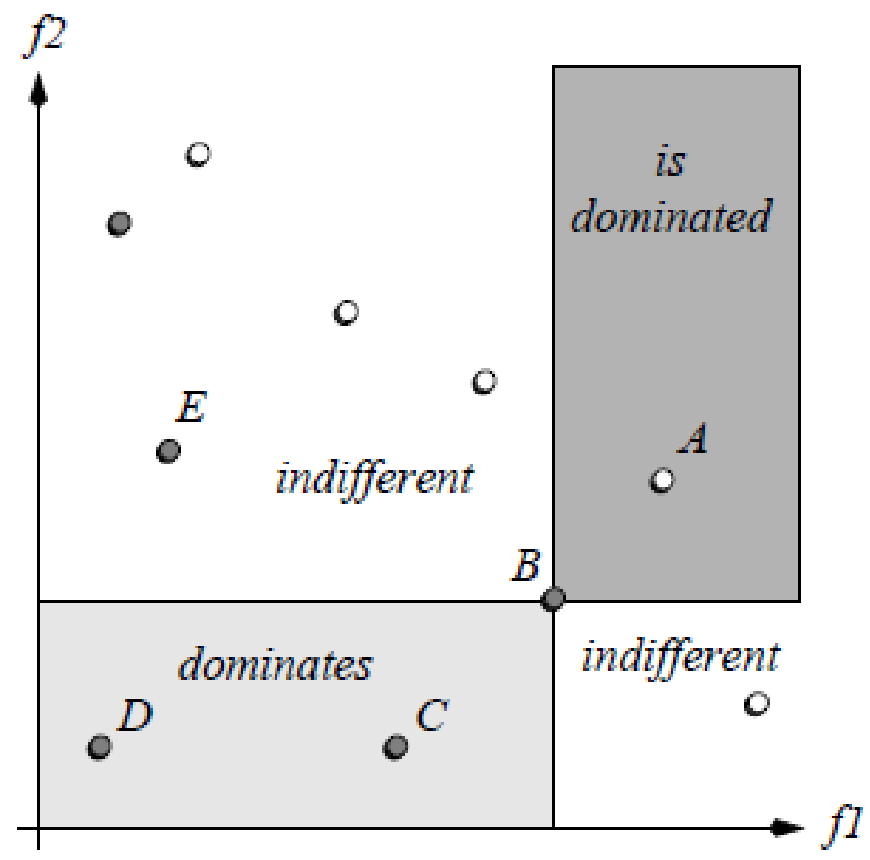

Gambar 2. Dominasi Pareto

(1) Himpunan $A$ dinyatakan sebagai himpunan Pareto optimal lokal jika hanya jika $\forall a \in$ $A, \nexists x \in X_{f}$ sehingga $x>a \wedge\|x-a\|<\varepsilon$ dan $\|f(x)-f(a)\|<\delta$ dimana $\|\cdot\|$ adalah metrik jarak, $\varepsilon>0, \delta>0$.

(2) Himpunan A dinyatakan sebagai himpunan Pareto optimal global jika hanya jika $\forall a \in$ $A, \nexists x \in X_{f}$ sehingga $x \succ a$.

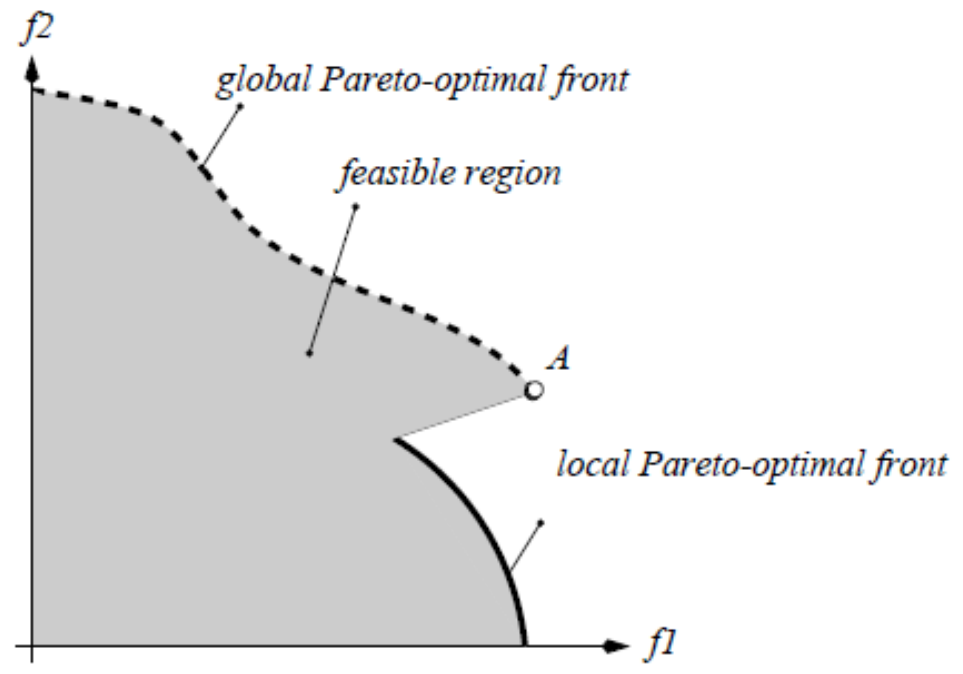

Gambar 3. Local Pareto-optimal front dan Global Pareto-optimal front 
Garis putus-putus pada Gambar 3 merupakan himpunan Pareto optimal global (Global Pareto-optimal front) dan garis tebal merupakan himpunan Pareto optimal lokal (local Paretooptimal front).

3.2. Metode Pembobotan (Weighted Sum Method). Berdasarkan pembahasan mengenai Pareto optimality di atas, solusi optimal yang diperoleh bukan berupa satu titik melainkan kumpulan beberapa titik, yang kesemuanya memenuhi konsep Pareto optimality. Kumpulan titik-titik tersebut adalah himpunan optimal Pareto, karena semua titik tersebut mendominasi titik-titik yang lain. Selanjutnya, himpunan penyelesaian optimal Pareto yang dihasilkan dapat dianalisa oleh pengambil keputusan.

Banyak pendekatan yang ada untuk menghasilkan penyelesaian optimal Pareto dari semua solusi optimal Pareto dengan bidang konveks, namun metode paling umum digunakan adalah metode pembobotan (weighted sum method) [2]. Sedangkan, metode perpangkatan-p berbobot dan metode minimaks berbobot adalah merupakan versi peningkatan dari metode pembobotan untuk menangani masalah nonkonveks. Namun, pada penelitian ini metode yang akan dibahas adalah metode pembobotan untuk bidang konveks.

Ide dasar metode ini adalah mengkombinasikan semua tujuan menjadi satu fungsi tujuan tunggal. Setiap fungsi tujuan diberi pembobot yang mewakili preferensi pengambil keputusan terhadap masing-masing tujuan, kemudian baru dijumlahkan. Pembobot tersebut merupakan parameter yang dapat divariasikan secara sistematik untuk menghasilkan penyelesaian optimal.

Masalah optimisasi multiobjektif diubah ke masalah optimisasi single objektif yang membentuk kombinasi linear dari fungsi objektif:

$$
\begin{aligned}
& \text { Maksimumkan:y }=f(x)=w_{1} \cdot f_{1}(x)+w_{2} \cdot f_{2}(x)+\cdots+w_{k} \cdot f_{k}(x) \\
& \text { dengan kendala: } x \in X_{f} \\
& \text { denganw }_{i} \text { adalah bobot, dan } \sum_{i=1}^{k} w_{i}=1
\end{aligned}
$$

Menyelesaikan masalah optimisasi (4) untuk sejumlah kombinasi bobot yang berbeda dan tertentu menghasilkan himpunan penyelesaian. Pada kondisi bahwa algoritma optimisasi yang tepat telah digunakan dan semua bobot positif, maka metode ini hanya akan menjadi solusi optimal Pareto. Hal ini dijamin oleh Lemma 3.5.

Didefinisikan $W=\left\{w=\left(w_{1}, w_{2}, \ldots, w_{k}\right) \mid w_{i} \geq 0\right.$ dan $\left.\sum_{i=1}^{k} w_{i}=1\right\}$. Dibentuk kombinasi linier konveks dari fungsi-fungsi objektif yaitu $f(x)=\sum_{i=1}^{k} w_{i} \cdot f_{i}(x)$. Lemma 3.5 berikut menjelaskan bahwa pemaksimum dari $f(x)=\sum_{i=1}^{k} w_{i} \cdot f_{i}(x)$ merupakan optimal Pareto.

Lemma 3.5. Diberikan $w \in W$. Jika $\hat{x} \in X_{f}$ pemaksimum $\sum_{i=1}^{k} w_{i} \cdot f_{i}(x)$, maka $\hat{x}$ adalah Pareto optimal untuk masalah optimisasi (4).

Bukti. Diketahui $w \in W$ dan $\hat{x}$ pemaksimum $\sum_{i=1}^{k} w_{i} \cdot f_{i}(x)$. Andaikan $\hat{x}$ bukan Pareto optimal maka terdapat penyelesaian yang didominasi yaitu $\bar{x}$ sehingga:

$$
f_{i}(\bar{x}) \geq f_{i}(\hat{x}), i=1,2, \ldots, k
$$

dan $f_{j}(\bar{x})>f_{j}(\hat{x})$ untuk paling sedikit satu j. Akibatnya,

$$
\begin{aligned}
w_{1} \cdot f_{1}(\bar{x})+w_{2} \cdot f_{2}(\bar{x})+\ldots+w_{k} \cdot f_{k}(\bar{x}) & >w_{1} \cdot f_{1}(\hat{x})+w_{2} \cdot f_{2}(\hat{x})+\ldots+w_{k} \cdot f_{k}(\hat{x}) \\
\sum_{i=1}^{k} w_{i} \cdot f_{i}(\bar{x}) & >\sum_{i=1}^{k} w_{i} \cdot f_{i}(\hat{x})
\end{aligned}
$$


Dengan kata lain $\hat{x}$ bukan pemaksimum $\sum_{i=1}^{k} w_{i} \cdot f_{i}(x)$. Hal ini kontradiksi dengan yang diketahui bahwa $\hat{x}$ pemaksimum $\sum_{i=1}^{k} w_{i} \cdot f_{i}(x)$. Sehingga $\hat{x}$ adalah Pareto optimal.

Misalkan untuk $k=2$ maka untuk bobot tertentu $w_{1}, w_{2}$ solusi $x$ dapat dicari untuk memaksimalkan $y=w_{1} \cdot f_{1}(x)+w_{2} \cdot f_{2}(x)$. Selanjutnya, persamaan ini dapat dibentuk sebagai

$$
f_{2}(x)=-\frac{w_{1}}{w_{2}} \cdot f_{1}(x)+\frac{y}{w_{2}}
$$

yang mendefinisikan suatu garis dengan gradien kemiringan $-\frac{w_{1}}{w_{2}}$ dan pembatas $\frac{y}{w_{2}}$ dalam ruang objektif. Secara grafik, proses optimisasi berkorespodensi untuk mengubah garis ini menjadi naik sampai tidak ada vektor objektif yang feasible diatasnya dan paling tidak satu vektor objektif yang feasible (dalam Gambar 4, A dan D) di garis tersebut. selanjutnya B dan C tidak akan pernah memaksimalkan $f$. Jika kemiringan dinaikkan, D mencapai nilai lebih besar dari $f$, jika kemiringan diturunkan A mempunyai nilai $f$ lebih besar daripada $\mathrm{B}$ dan $\mathrm{D}$.

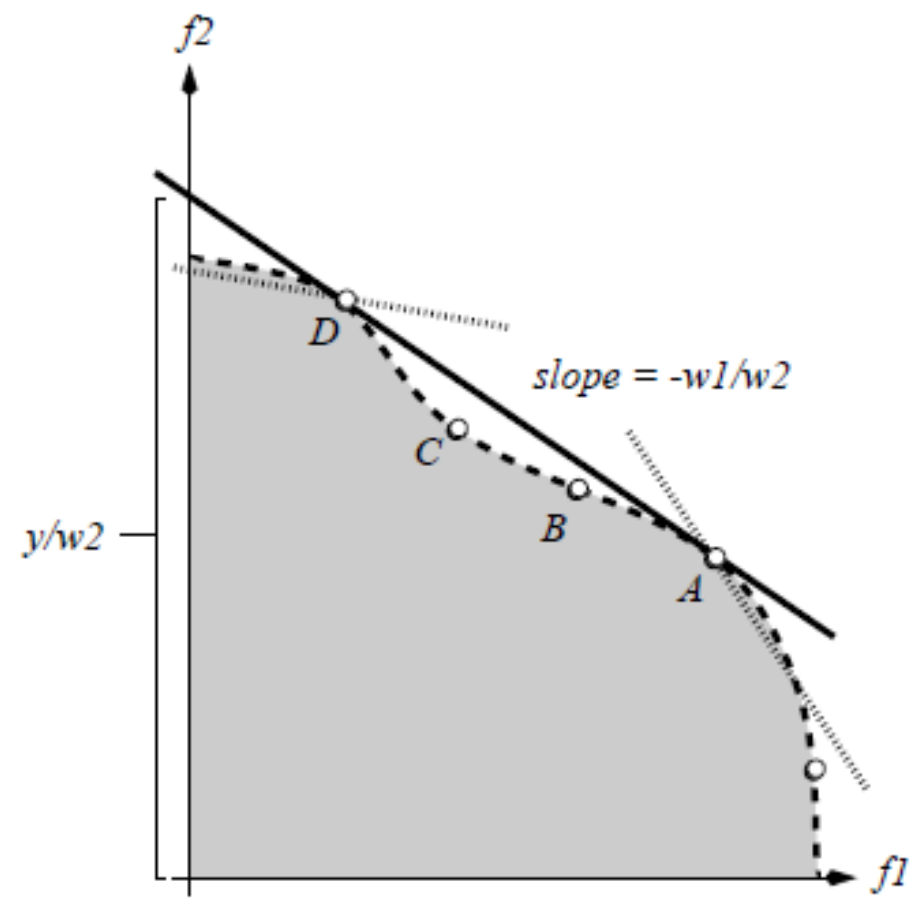

Gambar 4. Ilustrasi Metode pembobotan

3.3. Contoh. Untuk memperjelas uraian pembahasan di atas perhatikan contoh masalah optimisasi multiobjektif nonlinear berikut.

$$
\begin{aligned}
& \text { Maksimumkan: } f(x)=\left(f_{1}(x), f_{2}(x)\right) \\
& \text { dengan: } \\
& f_{1}(x)=\left(x_{1}+1\right)^{2}+\left(x_{2}+1\right)^{2} \\
& f_{2}(x)=\left(x_{1}-1\right)^{2}+\left(x_{2}+1\right)^{2} \\
& \text { dengan kendala: } e(x)=\left(e_{1}(x), e_{2}(x)\right) \leq 0 \\
& \text { dengan: } \\
& e_{1}(x)=x_{1}-2 \\
& e_{2}(x)=x_{1}+4 x_{2}-10 \\
& x_{1}, x_{2} \geq 0
\end{aligned}
$$


Dari masalah optimisasi (5) dapat dilihat bahwa $x=\left(x_{1}, x_{2}\right) \in X$ adalah vektor keputusan dan $y=\left(y_{1}, y_{2}\right) \in Y$ dalah vektor objektif, dimana $X$ adalah ruang keputusan dan $Y$ disebut ruang objektif. Himpunan feasible dari masalah optimisasi (5) dapat dengan mudah ditentukan dengan metode grafik, yaitu seperti pada gambar di bawah ini:

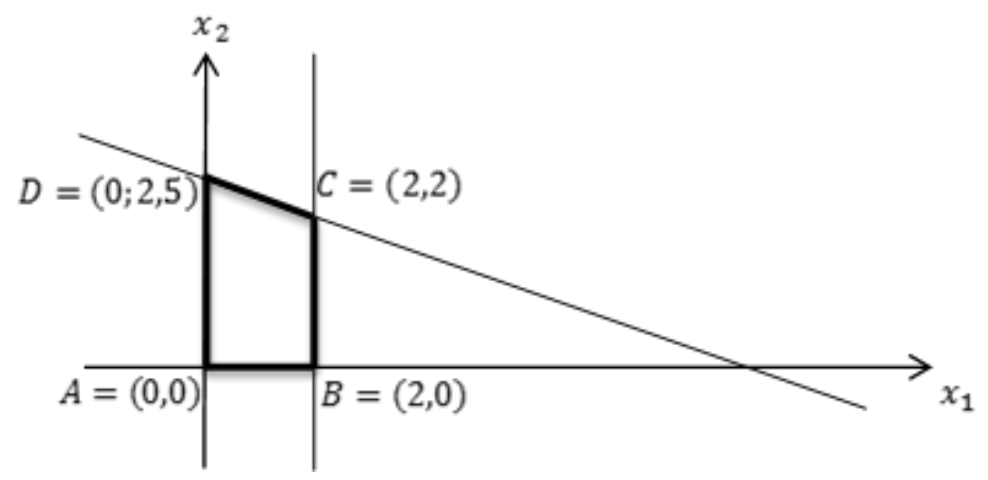

Gambar 5. Himpunan Feasible ruang keputusan $X$ dari masalah optimisasi (5)

Segi empat ABCD pada Gambar 5, merupakan himpunan feasible dari masalah optimisasi (5), pada ruang keputusan. Selanjutnya akan diberikan daerah feasible pada ruang objektif, yaitu:

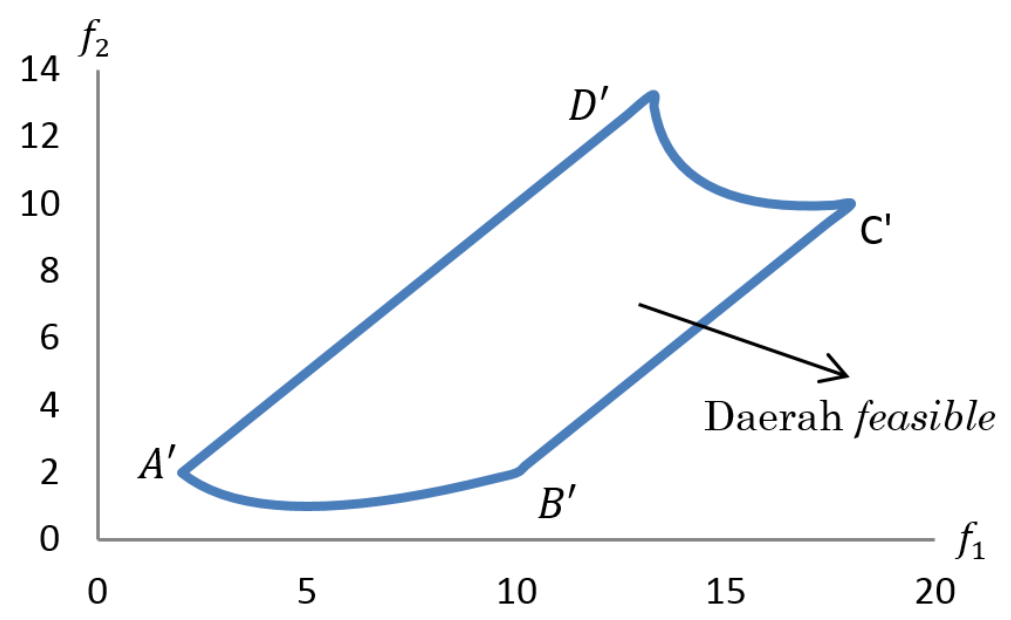

Gambar 6. Daerah feasible ruang objektif $Y$ dari masalah optimisasi (5)

Pada Gambar 6, segiempat $A^{\prime} B^{\prime} C^{\prime} D^{\prime}$ merupakan daerah feasible dari masalah optimisasi (5), pada ruang objektif.

Selanjutnya, perhatikan himpunan feasible dari masalah optimisasi multiobjektif (5), segiempat ABCD pada Gambar 5. Pada Tabel 1 berikut diberikan nilai fungsi di titik-titik batas himpunan feasible.

Dari Tabel 1 dapat dilihat bahwa:

(1) Untuk dua vektor keputusan $a=(0,0)$ dan $b=(2,0), b \succcurlyeq a$ ( $b$ mendominasi lemah $a)$, artinya $f(b) \geq f(a)$.

(2) Untuk dua vektor keputusan $b=(2,0)$ dan $c=(2,2), c \succ c$ (c mendominasi kuat $b$ ), artinya $f(c)>f(b)$. Perhatikan bahwa $f(b) \geq f(a)$, oleh karena itu $f(c)>f(a)$, artinya $c \succ a(c$ mendominasi kuat $a)$ 
TABEL 1. Nilai fungsi di titik-titik batas himpunan feasible

\begin{tabular}{ccccc}
\hline & $x_{1}$ & $x_{2}$ & $f_{1}$ & $f_{2}$ \\
\hline $\mathrm{A}$ & 0 & 0 & 2 & 2 \\
$\mathrm{~B}$ & 2 & 0 & 10 & 2 \\
$\mathrm{C}$ & 2 & 2 & 18 & 10 \\
$\mathrm{D}$ & 0 & 2,5 & 13,25 & 13,25 \\
\hline
\end{tabular}

(3) Untuk dua vektor keputusan $c=(2,2)$ dan $d=(0 ; 2,5), c \sim d$ (c indifferent dengan d), artinya $f(c) \ngtr f(d) \wedge f(c) \nsupseteq f(d)$.

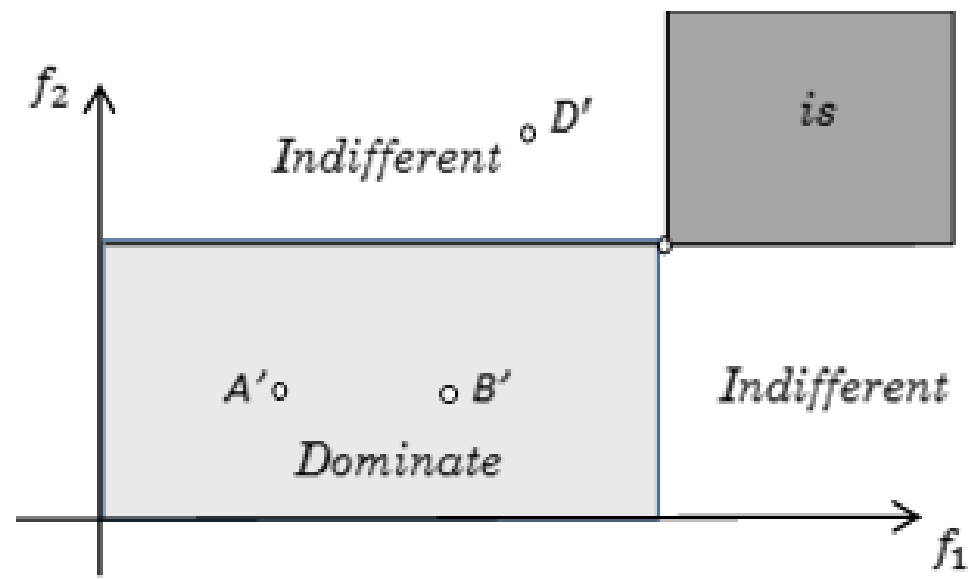

Gambar 7. Dominasi Pareto dari masalah optimisasi (5)

Pada Gambar 7, segiempat berwarna abu-abu terang memuat vektor objektif pada ruang objektif yang didominasi oleh $C$. Segiempat bewarna abu-abu gelap memuat vektor objektif pada ruang objektif yang mendominasi $C$. Penyelesaian dari masalah optimisasi ini tidak akan berada pada kedua segi empat ini.

Perhatikan vektor keputusan $c=(2,2)$. Vektor keputusan $c=(2,2)$ merupakan Pareto optimal, sebab tidak ada $x \in X_{f}$ yang mendominasi $c$. Selanjutnya perhatikan vektor keputusan $d=(0 ; 2,5)$, juga merupakan Pareto optimal, sebab tidak ada $x \in X_{f}$ yang mendominasi d. Jika semua Pareto optimal dikumpulkan maka akan diperoleh himpunan Pareto optimal. Berdasarkan Definisi 5 himpunan Pareto optimal dari masalah optimisasi ini adalah seperti pada Gambar 8.

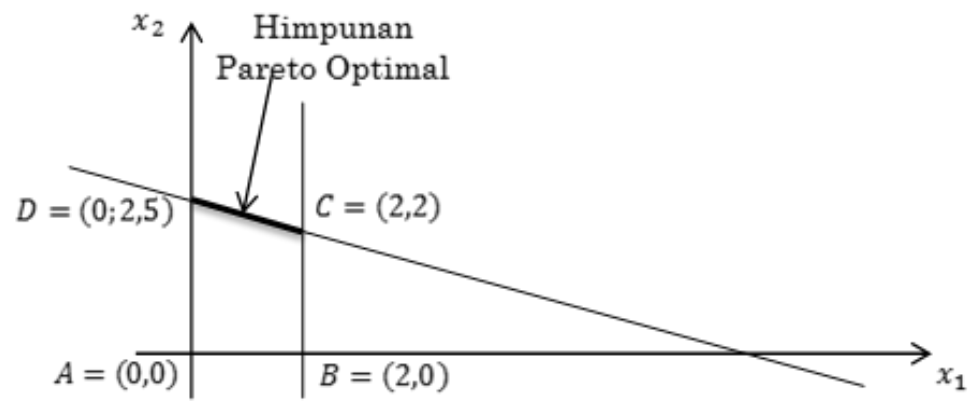

Gambar 8. Himpunan Pareto optimal dari masalah optimisasi (5) 
Garis yang dicetak tebal pada Gambar 8 menunjukkan himpunan Pareto optimal untuk masalah optimisasi (5). Himpunan korespondensi dari himpunan Pareto optimal disebut Pareto-optimal front. Pareto-optimal front dari masalah optimisasi (5) adalah seperti Gambar 9 .

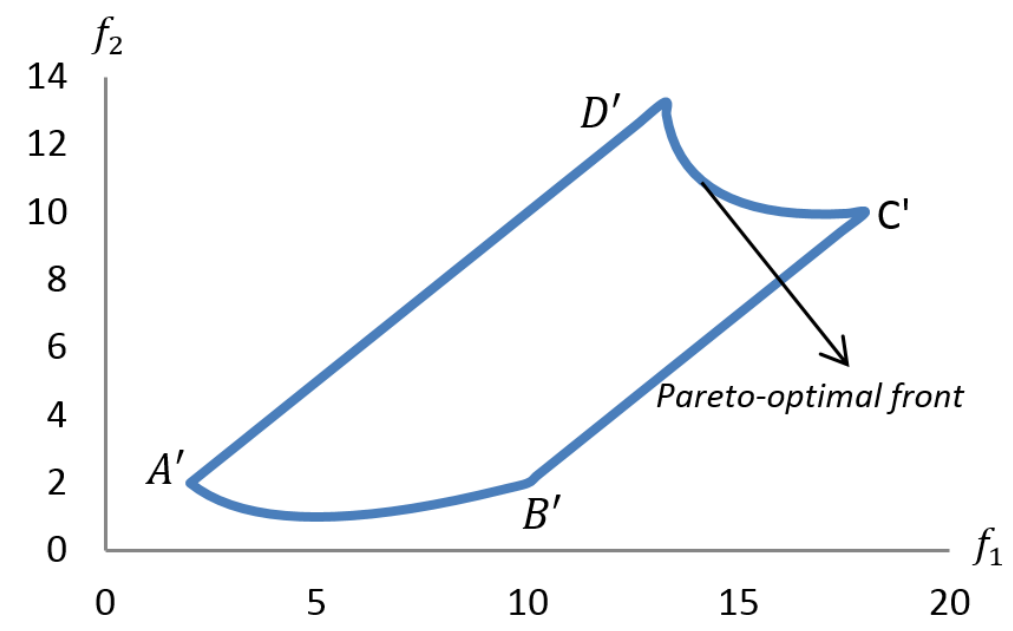

Gambar 9. Pareto-optimal front dari masalah optimisasi (5)

Berdasarkan Definisi 7 diperoleh bahwa himpunan Pareto optimal pada masalah optimisasi (5) ini merupakan himpunan Pareto optimal global, sebab untuk setiap anggota himpunan Pareto optimal tidak ada anggota himpunan layak yang mendominasi anggota himpunan Pareto optimal tersebut. Artinya $\forall x \in X_{p}, \nexists \tilde{x} \in X_{f}$ sehingga $\tilde{x} \succ x$.

Perhatikan kembali masalah optimisasi multiobjektif (5) yang diberikan di atas. Dengan metode pembobotan masalah optimisasi (5) dapat dituliskan sebagai berikut:

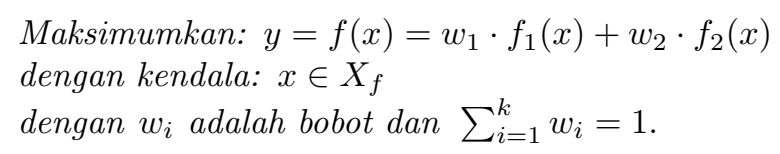

Dengan memvariasikan $w_{i}$ maka akan diperoleh himpunan penyelesaian. Jika dipilih $w_{1}=0,4$ dan $w_{2}=0,6$ maka masalah optimisasi (6) menjadi:

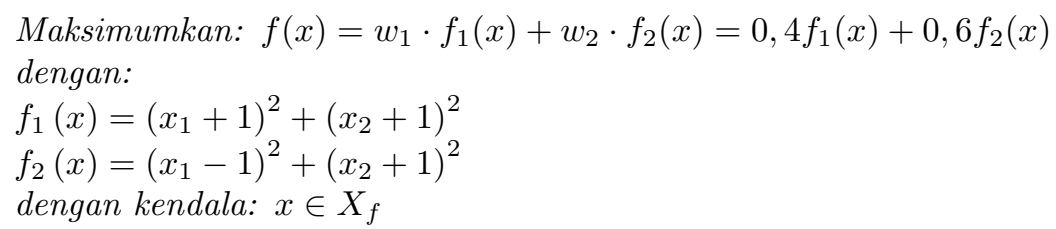

Masalah optimisasi (7) merupakan masalah optimisasi single objektif. Selanjutnya masalah optimisasi ini dapat dengan mudah diselesaikan dengan metode grafik. Jika masalah optimisasi ini diselesaikan dengan metode grafik maka akan diperoleh penyelesaian optimumnya adalah $x=(0 ; 2,5)$.

Jika dipilih $w_{1}=0,5$ dan $w_{2}=0,5$ maka masalah optimisasi (6) menjadi:

Maksimumkan: $f(x)=w_{1} \cdot f_{1}(x)+w_{2} \cdot f_{2}(x)=0,5 f_{1}(x)+0,5 f_{2}(x)$ dengan

$$
\begin{aligned}
& f_{1}(x)=\left(x_{1}+1\right)^{2}+\left(x_{2}+1\right)^{2} \\
& f_{2}(x)=\left(x_{1}-1\right)^{2}+\left(x_{2}+1\right)^{2} \\
& \text { dengan kendala: } x \in X_{f}
\end{aligned}
$$

Jika masalah optimisasi (8) diselesaikan dengan metode grafik maka akan diperoleh penyelesaian optimumnya adalah $x=(2,2)$. Selanjutnya solusi optimum untuk beberapa variasi nilai 
$w_{i}$ yang lain akan dituliskan dalam Tabel 2. Dari Tabel 2 dapat dilihat bahwa solusi optimum dari metode pembobot ini memang merupakan himpunan optimal Pareto.

TABEL 2. Solusi Optimum untuk beberapa variasi nilai $w_{i}$

\begin{tabular}{ccc}
\hline$w_{1}$ & $w_{2}$ & Solusi Optimum \\
\hline 0,3 & 0,7 & $(0 ; 2,5)$ \\
0,4 & 0,6 & $(0 ; 2,5)$ \\
0,5 & 0,5 & $(2,2)$ \\
0,6 & 0,4 & $(2,2)$ \\
0,7 & 0,3 & $(2,2)$ \\
\hline
\end{tabular}

\section{SIMPULAN}

Permasalaahn optimisasi multiobjektif adalah masalah optimisasi dengan beberapa fungsi tujuan (multi-objektif) yang harus dipenuhi secara simultan dan seringkali fungsi-fungsi tersebut saling bertentangan. Dalam kasus nonlinear, permasalahan ini dapat diselesaikan dengan menggunakan pendekatan Pareto front. Kumpulan solusi yang dihasilkan disebut himpunan pareto optimal (Pareto front). Himpunan Pareto optimal tersebut berkorespondensi dengan Pareto-optimal front. Jika Pareto-optimal front tersebut konveks, maka solusi masalah ini dapat diselesaikan dengan metode pembobotan (weighted sum method).

\section{DAFtar Pustaka}

[1] Diah Chaerani, E Erna, and Stanley P Dewanto. Model optimisasi linier integer untuk masalah pemilihan media periklanan dengan menggunakan pendekatan konsep set covering. Jurnal Matematika Integratif ISSN, 1412:6184, 2013.

[2] Vira Chankong and Yacov Y Haimes. Multiobjective decision making: theory and methodology. Courier Dover Publications, 2008.

[3] Bruce D Craven and Sardar MN Islam. Optimization in economics and finance: Some advances in non-linear, dynamic, multi-criteria and stochastic models, volume 7. Springer Science \& Business Media, 2005.

[4] Syarifah Inayati. Algoritma fuzzy goal programming untuk masalah pemrograman bilevel multiobjektif. Jurnal Ilmiah Matematika dan Pendidikan Matematika (JMP), 10(1), 2018.

[5] R Timothy Marler and Jasbir S Arora. The weighted sum method for multi-objective optimization: new insights. Structural and multidisciplinary optimization, 41(6):853-862, 2010.

[6] Eero Pätäri, Ville Karell, Pasi Luukka, and Julian S Yeomans. Comparison of the multicriteria decision-making methods for equity portfolio selection: The us evidence. European Journal of Operational Research, 265(2):655-672, 2018.

[7] Jong-hyun Ryu, Sujin Kim, and Hong Wan. Pareto front approximation with adaptive weighted sum method in multiobjective simulation optimization. In Proceedings of the 2009 Winter Simulation Conference (WSC), pages 623-633. IEEE, 2009.

[8] Ravindra Tappeta, John Renaud, and José Rodríguez. An interactive multiobjective optimization design strategy for decision based multidisciplinary design. Engineering Optimization, 34(5):523-544, 2002.

[9] Neswin Indara Widiarsi and Rosita Kusumawati. Pemrograman linear fuzzy dengan koefisien teknis bilangan fuzzy menggunakan metode fuzzy decisive set. Jurnal Matematika Integratif, 12(2):67-74, 2016.

[10] Fhani Mulyani Zenis, M Yusuf Fajar, and Yani Ramdani. Program linear multi-objective dengan fixed-weight method. Matematika, 14(1), 2015.

[11] Eckart Zitzler. Evolutionary algorithms for multiobjective optimization: Methods and applications, volume 63. Citeseer, 1999. 
